\title{
The Prospects of Blue Economy to Promote Bangladesh into a Middle-Income Country
}

\author{
Md. Monjur Hasan 1,2, B. M. Sajjad Hossain³, Md. Jobaer Alam, K. M. Azam Chowdhury, ${ }^{4,5}$ \\ Ahmad Al Karim6, Nuruddin Md. Khaled Chowdhury ${ }^{7,8}$
}

${ }^{1}$ School of Law and Political Science, Ocean University of China, Qingdao, China

${ }^{2}$ Department of Law, Gono Bishwabidyalay (University), Savar, Dhaka, Bangladesh

${ }^{3}$ University of Dhaka, Dhaka, Bangladesh

${ }^{4}$ Department of Oceanography, University of Dhaka, Dhaka, Bangladesh

${ }^{5}$ College of Oceanic and Atmospheric Sciences, Ocean University of China, Qingdao, China

${ }^{6}$ Ministry of Foreign Affairs, Government of the People's Republic of Bangladesh, Dhaka, Bangladesh

${ }^{7}$ Department of Geology, University of Dhaka, Dhaka, Bangladesh

${ }^{8}$ Department of Geosciences, Texas Tech University, Lubbock, USA

Email: hasan.ouc16@yahoo.com

How to cite this paper: Hasan, M.M., Hossain, B.M.S., Alam, M.J., Chowdhury, K.M.A., Al Karim, A. and Chowdhury, N.M.K. (2018) The Prospects of Blue Economy to Promote Bangladesh into a Middle-Income Country. Open Journal of Marine Science, 8, 355-369.

https://doi.org/10.4236/ojms.2018.83019

Received: May 1, 2018

Accepted: May 19, 2018

Published: May 22, 2018

Copyright $\odot 2018$ by authors and Scientific Research Publishing Inc. This work is licensed under the Creative Commons Attribution International License (CC BY 4.0).

http://creativecommons.org/licenses/by/4.0/

\begin{abstract}
This paper draws attention to the prospects of sea-based economy to promote Bangladesh in a middle-income country through the sustainable use of marine resources. About three-fourths of the earth is covered by the seas. It plays the vital role in two important functions from ancient time known as the means of communication and the source of huge living and non-living natural resources. At present, the countries are becoming very much concerned about their marine resources to resolve many of the present and future challenges of their economies. Generally for Bangladesh, ocean is contributing a significant role to its overall socio-economic progress through rising up the economic activities across the country and especially to the coastal zone at southern part. This paper investigates how much Bangladesh is capable to take of or handle the challenges to become a middle income country through the Sustainable Development Goals (SDGs). In addition, it has attempted with a closer-look to find out the barriers or limitations of these activities from different angles if exist.
\end{abstract}

\section{Keywords}

Blue Economy, Sustainable Development, Marine Resources, Middle-Income Country, Bangladesh

\section{Introduction}

The concept of Blue Economy has come into existence when the countries con- 
centrate on their marine resources. It has opened a new possibility for economic development of the coastal countries through utilizing sea and marine resources at national and international levels. This concept has become an exhortation for sustainable development. Since the marine resources are the only raw materials of blue economy so every country has to take the share of the responsibility to protect seas which cover 64 percent of the surface of our oceans and constitute more than 90 percent of the total [1]. Now it is high time to demonstrate measurable steps towards critical internationally agreed targets for several issues including fisheries, aquaculture, and habitat protection and pollution reduction and so on.

The concept of the oceans economy also referred to as the blue economy is one that simultaneously promotes economic growth, environmental sustainability, social inclusion and the strengthening of oceans ecosystems. However, no study has been conducted as to the present topic in Bangladesh perspective. Most of the researchers had conducted their study only on aquaculture or fishery especially shrimp while they overlook the wider oceans economy concept. As such, Deb, A.K. (1998) described that shrimp culture in the coastal areas of Bangladesh rapidly expanded in the last two decades in an unplanned and unregulated way which has impact on both environmental and socio-economic issues [2]. It reveals the fact that if the societal value of the coastal environment that supports life-and-livelihood of millions of coastal communities of Bangladesh is not recognized, aquaculture industry might give rise to severe ecological, economic and social problems and conflicts. The researcher made some comments how to improve the present situation and develop sustainable aquaculture leaving the concept of blue economy.

Hossain, M.S. (2001) states that the coastal and marine environment become increasingly important in fulfilling social and economic development and strategic objectives of the country [3]. But this study highlighted only the aquaculture as well as the fishery resources.

Hunt B., Vincent, A.C. (2002) conducted a research on marine bio prospecting issue and they found that the scanty information available suggests that marine bio prospecting for pharmaceuticals may have minimal impacts on the environment, particularly compared with those created by other pressures [4].

Creel, L. (2003) explained about demographic relation with ocean. The researcher stated that coastal regions, areas that are home to a large and growing proportion of the world's population are undergoing environmental decline [5]. The problem is particularly acute in developing countries. The reasons for environmental decline are complex, but population factors play a significant role. Today, approximately 3 billion people, about half of the world's population live within 200 kilometers of a coastal region. This study found that by 2025, this number is likely to double. The high concentration of people in coastal regions has produced many economic benefits, including improved transportation links, industrial and urban development, revenue from tourism, and food production. 
But the combined effects of booming population growth and economic and technological development are threatening the ecosystems that provide these economic benefits. Unless governments and users of coastal resources take action, population pressures and the associated levels of economic activity will further degrade many coastal habitats.

Research on sustainable blue economy as well as economic zone of Bangladesh is very rare. That is way, initiative has been taken and this study has tried to explore prospects of blue economy in Bangladesh. It confirms the prevailing views about the main challenges related to this sector.

\section{Sustainable Development}

Sustainable development is the organizing principle for meeting human development goals while at the same time sustaining the ability of natural systems to provide the natural resources and ecosystem services upon which the economy and society depend. The desirable end result is a state of society where living conditions and resource use continue to meet human needs without undermining the integrity and stability of the natural systems.

While the modern concept of sustainable development is derived mostly from the 1987 Brundtland Report, it is also rooted in earlier ideas about sustainable forest management and twentieth century environmental concerns [6]. As the concept developed, it has shifted to focus more on economic development, social development and environmental protection for future generations. It has been suggested that the term "sustainability" should be viewed as humanity's target goal of human-ecosystem equilibrium (homeostasis), while "sustainable development" refers to the holistic approach and temporal processes that lead us to the end point of sustainability [6].

\subsection{Oceans as a Key Factor in Sustainable Development Goals}

There is a need to mainstream the oceans economy into future Sustainable Development Goals. This effort should go beyond the previous Millennium Development Goal 7B related to fish stocks and protected marine areas.

This is particularly evident in proposed sustainable development goals number-14: Conserve and sustainability use the oceans, seas and marine resources for sustainable development, but also in other proposed goals such as 12 (sustainable production and consumption patterns), 13 (urgent action on climate change) and 15 (protection, restoration and promotion of sustainable use of ecosystems and biodiversity) and lightly over-lapping with few other points too.

Targets and indicators proposed under the goal 14 that are more relevant to the oceans economy include:

1) Reduction of marine pollution, including from land-based activities;

2) Sustainable management and protection of marine and coastal ecosystems;

3) Mitigation of the impacts of ocean acidification;

4) Regulation of fish harvesting with the aim of controlling over fishing; 
5) Restoration of fish stocks to ecologically safe levels;

6) Ensuring the full implementation of existing regional and international regimes on oceans and seas;

7) Elimination of IUU fishing and destructive fishing practices;

8) Elimination of subsidies which contribute to overcapacity and over fishing;

9) Providing access of small-scale and artisanal fishers to marine resources and markets; and increasing the economic benefits to Small Island Developing States (SIDS) and Least Developing Countries (LDCs) from the sustainable use of marine resources, including through sustainable management of fisheries, aquaculture and tourism.

Other additional elements that could be considered for incorporation in light of the ocean economy concept could include the following:

10) The development of access and benefit sharing rules for marine bio-prospecting (also related to conservation and innovation);

11) Investment in Research and Development (R \& D), infrastructural capacity and use of marine and other renewable energy sources (especially from offshore wind, tidal and waves, marine geothermal and biomass);

12) Availability of facilities and level of investment in sustainable coastal and maritime tourism and relevant infrastructure (also linked to conservation, employment and livelihoods).

\subsection{Blue Economy for Sustainable Development}

Gunter Pauli, through his book "The Blue Economy: 10 years, 100 innovations, 100 million jobs" [7] brought the Blue Economy concept into prominence. The Blue Economy is visualized as the integration of Ocean Economy development with the principles of social inclusion, environmental sustainability and innovative, dynamic business models. The Blue Economy can be defined as sustainable use of ocean resources for economic growth, improved livelihoods and jobs and ocean ecosystem health. Contribution of oceans and seas (as well as rivers, waterways and estuaries) in sustainable development is undeniable. Two thirds of the earth's surface is covered by water. The oceans are widely accepted as the incubator of all life forms. They are a fundamental yet delicate part of the Earth's biosphere and essential to sustaining life on the planet. Oceans serve a variety of purposes, all critical to the sustenance and preservation of human life. Among other things, they provide food and minerals, generate oxygen, absorb greenhouse gases (GHG), mitigate climate change, influence weather patterns and temperatures and serve as highways for human transport and sea-borne trade. The link between humans and the oceans has been fundamental to the development of human civilization. Today, more than 3 billion people live in close proximity to the coast [8]. This number is bound to rise with population growth too.

The oceans economy (also referred to as the blue economy) is a relatively new concept that has its origins in the green economy concept endorsed at the Unit- 
ed Nations Conference on Sustainable Development, held in Rio de Janeiro in 2012 (FAS, 2012). It shares the same desired outcome: the improvement of human well-being and social equity, while significantly reducing environmental risks and ecological scarcities. At its core the oceans economy refers to the de-coupling of socio-economic development from environmental degradation.

The concept of an oceans economy also embodies economic and trade activities that integrate the conservation and sustainable use and management of biodiversity, including maritime ecosystems, and genetic resources. It also seeks to contribute to mitigation and adaptation efforts to address climate change risks manifested in the rise of the sea level and the acidification of seawater. An oceans economy approach supports sustainable livelihoods and food security for sea-side countries and coastal populations. Globally, approximately 350 million jobs are linked to the oceans through fishing, aquaculture, coastal and marine tourism and research activities. Moreover, in excess 1 billion people depend on fish as their primary source of protein [9].

\section{Significance of Blue Economy}

According to Blue Economy Concept Paper (2012), Oceans cover $72 \%$ of the surface of our blue planet and constitute more than $95 \%$ of the biosphere. Life originated in the oceans and they continue to support all life today by generating oxygen, absorbing carbon dioxide, recycling nutrients and regulating global climate and temperature. Oceans provide a considerable portion of the global population with food and livelihoods and are the means of mass-transport for of global trade [10]. The marine and coastal environment also constitutes a key resource for the important global tourism industry; supporting all aspects of the tourism development cycle from infrastructure and the familiar "sun, sand and sea" formula to the diverse and expanding domain of nature-based tourism. The paper described, seabed currently provides $32 \%$ of the global supply of hydrocarbons with exploration expanding. Advancing technologies are opening new frontiers of marine resource development from bio-prospecting to the mining of seabed mineral resources. The sea also offers vast potential for renewable "blue energy" production from wind, wave, tidal, thermal and biomass sources. No dough, it is the largest root for mass transport and improving trade connectivity. However, advances in technology will significantly enhance access and capacity to extract additional marine resources in the coming decades.

\subsection{Blue Economy and Bangladesh}

Oceans provide a substantial portion of the global population with food and livelihoods. The marine and coastal environment also constitutes a key resource for the significant global tourism industry and expanding domain of nature-based tourism. Blue economy is a much used phrase these days internationally. Recently the term is widely spoken of in Bangladesh. The idea of "blue economy" has sparked interest in the country after the resolutions of the maritime boun- 
dary dispute with neighboring Myanmar [11] and India [12].

In the Bay of Bengal, Bangladesh now has a total of 121,110 square kilometers marine area including Exclusive Economic Zone (EEZ). With the marking of the maritime boundary, the government is now poised to formulate policies and mobilize resources. Blue Economy is one of the important tools available for achieving sustainable development for Bangladesh. Bangladesh being a coastal as well as riverine country depends heavily on its international shipping for the purpose of foreign trade. Figure 1 shows the geographical location of Bangladesh.

\subsection{Prospects of Blue Economic Zone in Bangladesh}

Bangladesh has vast coastal and marine resources along its south edge. Due to the geographical position and climatic condition, the coastal area of the country is known as one of the highly productive areas of the world. Bangladesh is rich not only in terms of its vast water areas but also in terms of the biological diversity. One of the unique features of the coastal areas is the influence of the mangrove forests, which support a high number of fishes and other commercially important aquatic organisms [13].

Bangladesh formed by a delta plain at the confluence of the several trans-boundary mighty rivers, in usually characterized by its typical geographical

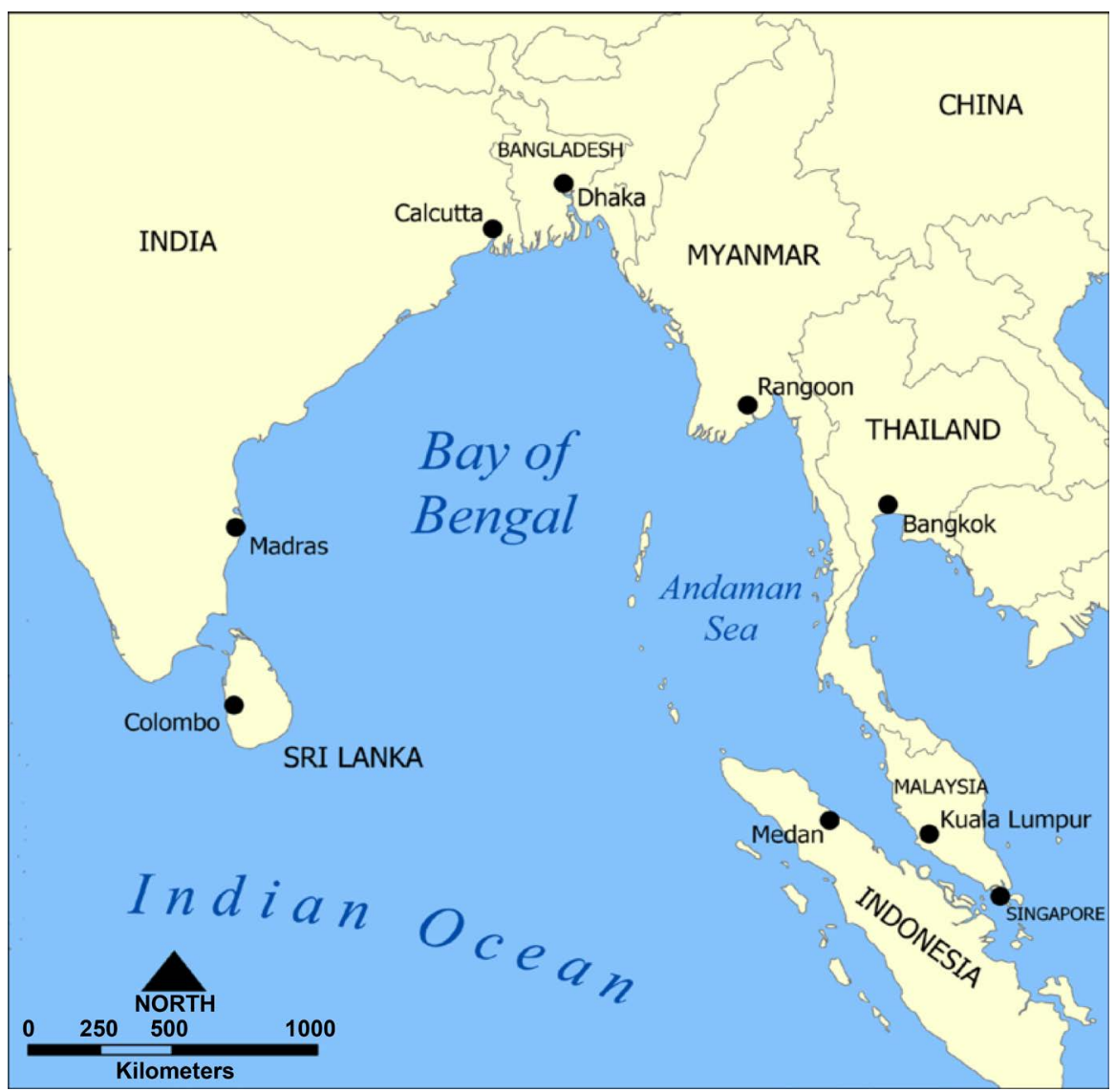

Figure 1. Geographical location of Bangladesh. 
settings, the Himalayan range in the North and the Bay of Bengal in the South. These two unique features historically shaped formation of major habitats and human habitation, social-economic structures, development priorities and, often, the basis of relationship and diplomacy with the neighbors and other south Asian countries. Country's $710 \mathrm{~km}$ long coast line extending from the tip of $S t$. Martin's Island in the southeast to the west coast of Satkhira and $121,110 \mathrm{~km}^{2}$ sea area are characterized with uniquely differentiated ecosystems having significant ecological and economic importance and potential [14]. There will be a human flow to the southern part of Bangladesh due to blue economic zone development. It will create employment opportunities and other income-generating activities, develop other social services, security services as well as the overall standard of life for the local people at coastal areas. Sector wise emphases are given below:

\section{1) Fishery}

A large number of commercially important fishes have long been exploited which are of high export values. Shrimp aquaculture has become a highly traded export-oriented industry now-a-days. In spite of having bright prospects, marine aquaculture on a commercial basis as well as marine stock enhancement and sea ranching are yet to be developed. The marine fisheries sector has been suffering from chronic disintegration and mismanagement that have led to many consequences. Most of the commercially important fish stocks are either over-exploited or under threat. Marine pollution has reached a level that could create an unmanageable situation in the near future; coastal shrimp farming has generated considerable debates due to its adverse environmental and socio-economic impacts [13].

Globally 350 million jobs are linked to marine fisheries, with $90 \%$ of fishers living in developing countries. The value of fish traded by developing countries is estimated at US\$25 billion making it their largest single trade item (UN, 2012).

Fishing activities will continue to represent a large part of economic and food output for many developing countries. As demand for fish continues to grow, Bangladesh needs to explore options to keep benefiting from this activity while ensuring sustainable management of stocks too.

\section{2) Aquaculture}

Aquaculture offers huge potential for the provision of food and livelihoods, though greater efficiency in provision of feed to aquaculture need to be realized, including reduced fish protein and oil and increased plant protein content, if the industry is to be sustainable. Aquaculture under the Blue Economy will incorporate the value of the natural capital in its development, respecting ecological parameters throughout the cycle of production, creating sustainable, decent employment and offering high value commodities for export.

Aquaculture is the fastest growing global food sector now providing $47 \%$ of the fish for human consumption [15]. As the demand for fish continues to grow 
and the availability of wild-capture fish decreases, there will be a greater role for aquaculture to augment the wild capture supply and ensure that wild stocks for Bangladesh.

\section{3) Food Security}

One billion people in developing countries like Bangladesh depend on seafood for their primary source of protein. Besides this all around the globe, a lot of people like seafood. Oceans can be the biggest sources for food for all the developing countries and may help to meet the challenges of food security issue too.

\section{4) Tourism}

Tourism is a major global industry. A large portion of global tourism is focused on the marine and coastal environment and it is set to rise. Trends in aging populations, rising incomes and relatively low transport costs will make coastal and ocean locations ever more attractive. Cruise tourism is the fastest growing sector in the leisure travel industry. It was 16 million in 2011 [16].

According to the United Nations World Tourism Organization (UNWTO), approximately one of every two tourists visited the seaside [17]. However it may open business and employment scope through new hotel, restaurant or other entertainment industry etc. In 2012, for the first time, the number of international tourist arrivals reached over one billion. Sustainable tourism is an essential economic sector for many developing countries like Bangladesh, which may contribution to the national income, foreign exchange earnings and investment. Sustainable tourism needs to be mainstreamed into national and regional planning as well as into technical cooperation, public financial support and public-private partnerships.

\section{5) Shipping and Maritime Transport}

Shipping is the lifeblood of the global economy. In today's globalized world, ports play a strategic role for the national trade and economy. The coastal and marine fisheries have been playing considerable roles not only in the social and economic development of the country but also in the regional ecological balance. Estimates suggest some 30 million Bangladeshi directly depend on oceanic economic activities like fisheries and commercial transportation [13].

About half of the world's population, most of its largest cities and industries along with critical value chains tend to be concentrated in coastal areas to ensure access to transport routes and continuous flows of resources and products [5]. Without oceanic and sea routes, globalization as we know it would not have been possible. Maritime transport is very important for Bangladesh as its social-economic prospects largely depend on their ability to connect to the rest of the world and access international markets.

\section{6) Renewable Marine Energy}

In 2009 offshore fields accounted for $32 \%$ of worldwide crude oil production and this is projected to rise to $34 \%$ in 2025 [18]. Oil will remain the dominant energy source for many decades to come but the Ocean offers enormous potential for the generation of renewable energy-wind, wave, tidal, biomass, thermal 
conversion and salinity gradients. Demand for renewable energy is expected to increase two and a half times by 2035 all over the world and Bangladesh is not exception of it.

The generation of renewable energy from tides and waves, wind turbines located in offshore areas, submarine geothermal resources and marine biomass could be viable alternatives for contributing to energy needs and climate change mitigation objectives. For Small Island Developing State (SIDS), such renewable energy sources could help diversify their energy portfolios and secure higher levels of energy security. Of all the marine sources, the highest potential for electricity generation is in the offshore wind turbines sector. Global offshore wind capacity is growing at the incredible rate of 40 per cent per year, producing 7100 megawatts of electricity in 2013 [19].

\section{7) Biotechnology and Medical Technology}

The global market for marine biotechnology products and processes is currently estimated at US $\$ 2.8$ billion and projected to grow to around US $\$ 4.6$ billion by 2017. Marine bio-tech has the potential to address a suite of global challenges such as sustainable food supplies, human health, energy security and environmental remediation [20]. Marine bacteria are a rich source of potential drugs. In 2011 there were over 36 marine derived drugs in clinical development, including 15 for the treatment of cancer. One area where marine bio-tech may make a critical contribution is the development of new antibiotics [4]. The potential scope is enormous; by 2006 more than 14,000 novel chemicals had been identified by marine bio-prospecting and 300 patents registered on marine natural products. On the energy front algal bio-fuels offer promising prospects. The European science Foundation postulates a production volume of 20 - 80 thousand liters of oil per hectare per year can be achieved from micro algal culture, with even the lower part of this range being considerably higher than terrestrial bio-fuel crops [21].

\subsection{Blue Economic Zone of Bangladesh: Corridor to Middle-Income Country}

World Bank (2014) reported that middle-income economies are those with a Gross National Income (GNI) per capita of more than US\$ 1045 but less than US\$12,746. Bangladesh was found in lower-middle-income country category in the year 2014, as it achieved US\$1080.00 which was only US\$ 958 in the year 2013.

Bangladesh Bureau of Statistics (BBS) published that the per capita income in Bangladesh rose from $\$ 1190$ to $\$ 1314$ on May 14, 2015 [22].

Gimenez, et al. (2014) stated that the vision 2021 plan and the associated perspective plan 2010-2021, adopted by the Government of Bangladesh lay out a series of development targets for 2021 [23]. Among the core targets identified to monitor the progress toward the vision 2021 objectives is that of attaining a poverty headcount of 14 percent by 2021 . The rate of poverty headcount was about 28.5 percent by 2015 , which significantly ahead of scheduled at Millennium De- 
velopment Goal (MDG). Attaining the vision 2021 poverty target of 14 percent by 2021, however, is less certain as it requires a Gross Domestic Product(GDP) growth of at least 8 percent, or more than 2 percentage points higher than that observed in recent years.

According to the Bangladesh Bureau of Statistics (2016) records, GDP in Bangladesh was 7.11\% in FY: 2015-2016 at Bangladesh and estimated to be increased at 7.20 in 2017 (BBS, 2016). So, the trend is positive, and if Bangladesh cannot utilize all the possible scopes as exporting sectors, marine resources, it may not be possible to become a Middle Income Country within the expected year by 2021.

Bangladesh has an aim to graduate from the Least Development Country (LDC) status to that of a middle income country by 2021 as per the United Nations' classification. In this context, it is very important to assess the capacity of the country's social infrastructure in achieving the desired level of economic growth rate and subsequently the targeted per capita income level [24].

The marine resources are described, while emphasis is given to living resources, particularly ecosystems and fisheries. Of the inter-tidal ecosystems, mangroves are the most diverse and highly productive and very important regionally. Considering the major regional and global context, fisheries and aquaculture are important, particularly for penaeid shrimp (Penaeus monodon) and also for pomfret, hilsa shed, bombay duck, mackerel, eel, ribbon fish, snapper, cat fish and Indian salmon [3].

Bangladesh can develop the port facility, capacity as well as increase in numbers too. Having more ports and developing the existing two more ports will be lower operating costs, even from the higher sized of vessels too. Including tourism all the scopes can help to attend the goals accordingly (See Figure 2). More business activity will increase the employment opportunity for Bangladeshi people too which will directly help to attend the required level of GDP to become a middle income country.

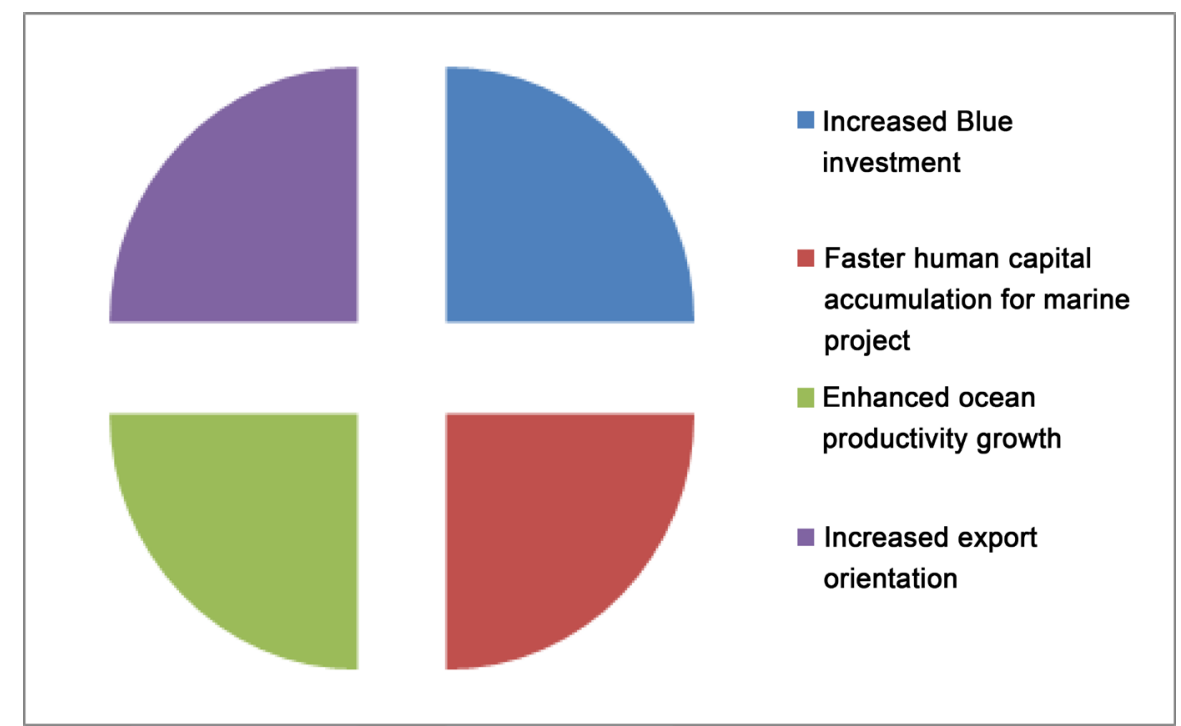

Figure 2. Blue economic zone utilization. 


\section{Challenges for Blue Economy Concept}

At the core of the Blue Economy concept is the de-coupling of socio-economic development from environmental degradation. To achieve this, the Blue Economy approach is founded upon the assessment and incorporation of the real value of the natural (blue) capital into all aspects of economic activity (conceptualization, planning, infrastructure development, trade, travel, renewable resource exploitation, energy production/consumption).

The Blue Economy approach recognize and places renewed emphasis on the critical need for the international community to address effectively the sound management of resources in and beneath international waters by the further development and refinement of international law and ocean governance mechanisms. In the Rio+20 outcome documents, "The future we want", UN Member States, committed to: "protect, and restore, the health, productivity and resilience of oceans and marine ecosystems, to maintain their biodiversity, enabling their conservation and sustainable use for present and future generations" [25].

Governance of the oceans and seas is a key global challenge. The number of international conventions and regional agreements makes it very difficult to ensure effective participation by coastal countries. Therefore, there is an increasing need for regulation on the basis of an appropriate balance between the demand for ocean's natural resources and their sustainability. Oceans are facing significant existential ecological risks that can negatively affect the social and economic prospects of all countries, particularly poor countries that are acutely dependent on oceans.

Climate change, increased emissions of carbon dioxide, over exploitation and poor management of marine resources including fisheries, waste-water runoff, pollutants into waterways-all are need to be considered seriously while the focus only into the economic development.

Sustainable use of oceans is critical to poverty reduction, food security, livelihood sustainability and mitigating climate change. As un-managed mass tourism may negatively impact coastal ecosystems depending on its impact which also be linked to the sustainable use of marine protected areas. Renewable energy, water treatment, marine wildlife watch and ecosystem conservation also have close synergistic relations with sustainable tourism. The pollution generated by maritime transport, and especially ship-source oil is also a large concern issue today.

Indeed, blue economy is very sensitive as it is related to ecosystem services, food security and the impacts of human activity. Noted issue is that the over exploitation and poor management of marine resources have resulted in lost opportunities, heightened food insecurity and diminished economic opportunities for some of the world's poorest people too.

\section{Measures to Overcome the Challenges}

With a view to improving food security, eradicating poverty and delivering 
shared prosperity, global leaders, ocean practitioners, scientists, and representatives from government, businessmen, civil society and international organizations must come together to explore action-oriented partnerships, governance arrangements, investment frameworks and financing vehicles to turn the tide not only on the health of oceans but also how the resources of the sea could be used for economic emancipation. The Functions of Blue economic zone to be utilized to become a Middle Income Country (MIC) are described at Table 1.

Proper attention is needed in every aspect of exploitation, handling and processing, export and marketing as well as in biological and institutional management strategies. The Bay of Bengal has been increasingly important for local development as well as for a global perspective. The coastal and marine fisheries of the Bay of Bengal are briefly reviewed in this paper to provide a salient feature of the available information and resource base and to identify future research and management needs [13].

Table 1. Function of blue economic zone to be middle income country.

\begin{tabular}{|c|c|c|}
\hline Area of Interest & Functions & Suggestions \\
\hline Fishing & $\begin{array}{l}\text { Capture fishery, Aquaculture and seafood } \\
\text { processing. }\end{array}$ & $\begin{array}{l}\text { 1) Upcoming Bangabandhu Satellite based monitoring system. } \\
\text { 2) Fish capture and protection capability increase. } \\
\text { 3) Promotion of environment friendly and sustainable shrimp, crab } \\
\text { and potentially important other species farming systems in the coastal } \\
\text { region. } \\
\text { 4) Mitigation and adaptive measures on the impacts of climate change. }\end{array}$ \\
\hline Minerals & $\begin{array}{l}\text { Oil and gas, deep-sea mining (exploration of } \\
\text { rare earth metals). }\end{array}$ & $\begin{array}{l}\text { 1) Determination of true potentiality of hydrocarbon reserve in the } \\
\text { Blue economic zone by establishing capability as well as foreign } \\
\text { support. }\end{array}$ \\
\hline $\begin{array}{l}\text { Marine Renewable } \\
\text { Energy }\end{array}$ & Solar, wind, wave and Tidal energy production. & $\begin{array}{l}\text { 1) Marine Renewable Energy mapping project to determine the true } \\
\text { potential. } \\
\text { 2) National and foreign investment. }\end{array}$ \\
\hline Marine Biotechnology & $\begin{array}{l}\text { Pharmaceuticals, chemicals, seaweed harvesting, } \\
\text { seaweed products, marine derived bio-products. }\end{array}$ & $\begin{array}{l}\text { 1) Mid and Long-term research on preservation, processing and quality } \\
\text { control of marine products. } \\
\text { 2) Encouragement of Sea food based restaurant and sea product based } \\
\text { industry. }\end{array}$ \\
\hline Marine Manufacturing & $\begin{array}{l}\text { Boat and ship manufacturing and repairing, } \\
\text { marine instrumentation, marine industrial } \\
\text { engineering. }\end{array}$ & 1) Loan and project to implement Maine manufacturing. \\
\hline $\begin{array}{l}\text { Port, Shipping \& } \\
\text { Maritime Logistics }\end{array}$ & $\begin{array}{l}\text { Ship building and repairing, ship owners and } \\
\text { operators, shipping agents and brokers, ship } \\
\text { management, container shipping services, } \\
\text { custom clearance, freight forwarders. }\end{array}$ & $\begin{array}{l}\text { 1) Sonadia deep (Island) seaport establishment. } \\
\text { 2) Capability building of three existing ports. } \\
\text { 3) Proper monitoring and management system and training. }\end{array}$ \\
\hline Marine Tourism & $\begin{array}{l}\text { Sunbath, Sailing and boating at sea, surfing, } \\
\text { scuba diving, swimming in the sea, bird } \\
\text { watching in coastal areas, whale, dolphin } \\
\text { watching, trips to the beach, seaside and islands. }\end{array}$ & $\begin{array}{l}\text { 1) Eco-friendly tourism. } \\
\text { 2) Safety and security. } \\
\text { 3) Easy communication system. } \\
\text { 4) Marine tourism zone. }\end{array}$ \\
\hline $\begin{array}{l}\text { Education and } \\
\text { Research }\end{array}$ & $\begin{array}{l}\text { Education and training, Research and } \\
\text { Development. }\end{array}$ & $\begin{array}{l}\text { Capability enhancement of maritime educational department, } \\
\text { institutions and research centre. }\end{array}$ \\
\hline
\end{tabular}




\section{Conclusion}

Efficient management and effective utilization of marine resources are of key importance for promoting Bangladesh in a middle-income country. Bangladesh has a huge possibility to enrich her economy with sea-based resources through ensuring a sustainable balance between the protection of marine ecosystem and marine resources. After the settlement of maritime boundary dispute with India and Myanmar, Bangladesh has gained a defined maritime zone in the Bay of Bengal. Now, Bangladesh can create more space to ensure her economic growth through new investments in marine trade and commerce. The World Bank Group identified job creation is the pre-condition to achieve middle-income country status for Bangladesh by 2021 [26]. So, it is the high time for Bangladesh to use millions of her unemployed youths creating more jobs opportunities for them. Bay of Bengal can be one of the important factors with its huge living and non-living marine resources to create enormous jobs opportunities for Bangladesh. Bangladesh government should go ahead with government and non-government joint investments through well-timed actions enacting exhaustive rules and regulations to ensure proper use of marine resources at the blue economic zone. If Bangladesh becomes able to utilize her marine resources actively, it is quite possible for her to be a middle-income country within short time. The present study has tried to point out the possible contribution of Blue Economy to make Bangladesh be a middle-income country in briefly. Further research may be necessary to make a detail account about the prospects of Blue Economy in the development of Bangladeshi Economy.

\section{References}

[1] Snelgrove, P. (Convenor), Berghe, E.V., Miloslavich, P., et al. (2016) Global Patterns in Marine Biodiversity, Chapter 34.

http://www.un.org/depts/los/global_reporting/WOA_RPROC/Chapter_34.pdf

[2] Dev, A.K. (1998) Fake Blue Revolution: Environmental and Socio-Economic Impacts of Shrimp Culture in the Coastal Areas of Bangladesh. Ocean \& Coastal Management, 41, 63-88. https://doi.org/10.1016/S0964-5691(98)00074-X

http://www.academia.edu/10376692/Fake_blue_revolution_environmental_and_soc io-economic_impacts_of_shrimp_culture_in_the_coastal_areas_of_Bangladesh

[3] Hossain, M.S. (2001) Biological Aspects of the Coastal and Marine Environment of Bangladesh. Ocean \& Coastal Management, 44, 261-282.

https://doi.org/10.1016/S0964-5691(01)00049-7

[4] Hunt, B. and Vincent, A.C.J. (2006) Scale and Sustainability of Marine Bioprospecting for Pharmaceuticals. AMBIO: A Journal of Human Environment, 35, 57-64. http://www.bioone.org/doi/abs/10.1579/0044-7447\%282006\%2935\%5B57\%3ASASO MB\%5D2.0.CO\%3B2

[5] Creel, L. (2003) Ripple Effects: Population and Coastal Region, Population Reference Bureau, 1-9.

https://books.google.com.br/books/about/Ripple_Effects.html?id=8qcltwAACAAJ\& redir_esc $=\mathrm{y}$

[6] Shaker, R.R. (2015) The Spatial Distribution of Development in Europe and Its Underlying Sustainability Correlations. Applied Geography, 63, 304-314. 
https://doi.org/10.1016/j.apgeog.2015.07.009

[7] Pauli, G. (2010) The Blue Economy: 10 Years, 100 Innovations, 100 Million Jobs. Paradigm Publications, United States, 386.

[8] BBC Online (2013) Sea-Level Rise Due to Climate Change Has Already Raised the Risk of Extreme Floods in Major Coastal Cities around the World, and Many Are Slowly Sinking into the Oceans.

http://www.bbc.com/future/story/20130613-the-rising-threat-to-our-cities

[9] World Bank (2012) The Living Oceans. http://go.worldbank.org/A2MYFIUQM0

[10] Blue Economy Concept Paper (2012) The Rio+20, United Nations Conference on Sustainable Development, 2012, Reo de Janeiro, Brazil. https://sustainabledevelopment.un.org/content/documents/2978BEconcept.pdf

[11] The Case of "Dispute Concerning Delimitation of the Maritime Boundary between Bangladesh and Myanmar in the Bay of Bengal”. International Tribunal for the Law of the Sea (ITLOS), 14 March 2012, Hamburg, Germany.

[12] The Case of "The Bay of Bay of Bengal Maritime Boundary Arbitration between the People's Republic of Bangladesh and Republic of India" Permanent Court of Arbitration, 7 July, 2014, The Hague, Netherlands.

[13] Islam, M.S. (2003) Perspectives of the Coastal and Marine Fisheries of the Bay of Bengal, Bangladesh. Ocean \& Coastal Management, 46, 763-796. https://doi.org/10.1016/S0964-5691(03)00064-4

[14] Islam, M.M. (2016) Bangladesh National Conservation Strategy: Coastal and Marine Resources. Sylhet Agricultural University, Bangladesh, 2-3.

[15] FAO (2010) Food and Agriculture Organization of the United Nations, Rome, 2010. FAO Fisheries and Aquaculture Department.

[16] FCCA (2012) Cruise Industry Overview 2011.

[17] United Nations World Tourism Organization (2013) Annual Report 2013.

[18] International Energy Agency (2011) World Energy Outlook 2011. IEA, Paris. http://www.iea.org/publications/freepublications/publication/weo2010.pdf

[19] Roney, J.M. (2013) 2013 to be Record Year for Offshore Wind. Earth Policy Institute. http://www.earth-policy.org/plan_b_updates/2013/update117

[20] UNESCO, IMO, FAO, UNDP (2011) A Blueprint for Ocean and Coastal Sustainability. Paris. http://unesdoc.unesco.org/images/0021/002150/215002e.pdf

[21] Leary, et al. (2009) Marine Genetic Resources: A Review of Scientific and Commercial Interest. Marine Policy, 33, 183-194.

https://doi.org/10.1016/j.marpol.2008.05.010

[22] Bangladesh Bureau of Statistics (2016) Annual Report 2015-2016.

[23] Giménez, L., Jolliffe, D. and Sharif, I. (2014) Bangladesh, a Middle Income Country by 2021: What Will It Take in Terms of Poverty Reduction? World Bank, Washington DC.

https://openknowledge.worldbank.org/handle/10986/18668?locale-attribute=en

[24] Raihan, S. (2016) Is Bangladesh all Set to Be a Middle Income Country? The Daily Star (A Daily Bangladeshi Newspaper), 06 March, 2016.

https://www.thedailystar.net/op-ed/bangladesh-all-set-be-middle-income-country-7 $\underline{86709}$

[25] Congressional Research Service (2012) Rio+20: The United Nations Conference on 
Sustainable Development. https://fas.org/sgp/crs/row/R42573.pdf

[26] World Bank (2016), Helping Bangladesh Reach Middle Income Country Status. http://www.worldbank.org/en/news/feature/2016/04/07/World_Bank_Group_s_Ne w_Country_Partnership_Framework_helps_Bangladesh_Reach_Middle_Income_C ountry_Status 